\title{
Commercial Nuisance: A Theory of Consumer Protection
}

The fraudulent practices of some merchants, since they deprive the poor of much of their income, not only offend law and ethics but also impede efforts to alleviate the poverty upon which those practices depend. ${ }^{1}$ In part, the solution to this problem will depend on the remedies available in the courts. Regulatory statutes have been passed in increasing numbers, ${ }^{2}$ and recent judicial expansion of the unconscionability doctrine indicates that judge-made law also may be increasingly important in affording relief. ${ }^{3}$ But because courts cannot act until cases are before them, expansion of substantive doctrine is unlikely to solve the problem, for the fraud which characterizes many retail transactions in poverty areas is largely dependent on the buyers' ignorance of their legal rights and the lack of available counsel. Further, buyers rarely have the financial resources to bring or defend an action. The sums at stake are low in comparison to the expenses of litigation, and since the fruit of victory is no more than rescission of the contract, success will not provide a lawyer's compensation. As a result, garnishment and attachment are frequently utilized to satisfy the amounts purportedly due. ${ }^{4}$

Every state has criminal penalties intended to regulate commercial transactions in some measure, but hesitancy to initiate criminal action

1 Such practices include selling reconditioned items as new, substituting low quality goods on delivery for those agreed upon in the store, and levying illegal credit charges. Other more subtle devices are written into the contract. Various provisions are designed to encourage default and retain legally unenforceable rights while many charges later collected are omitted from the contract in violation of disclosure statutes. Some devices are more original. One merchant included undated acknowledgement of debt clauses in his sales contracts so that if a buyer declared personal bankruptcy, the credit manager could fill in a later date and collect the debt. Workshop Discussions, Conference on Consumer Credit and the Poor, The University of Chicago Law School, Nov. 12-13, 1965. See generally Caplovitz, The Poor Pay More (1963).

2 See generally Gurran, Trends in Consumer Credit Legislation (1965).

3 See Williams v. Walker-Thomas Furniture Co., 350 F.2d 445 (D.C. Cir. 1965) (remanding action on installment contract for finding on defense of unconscionability); American Home Improvement, Inc. v. MacIver, 105 N.H. 435, 201 A.2d 886 (1964) (contract held unenforceable for violation of disclosure statutes and for unconscionable credit charge).

4 See CAPlovitz, op. cit. supra note 1, at 155-75; WALd, LAW AND PoverTY: 1965, at 22-30, 42-67 (1965); Carlin \& Howard, Legal Representation and Class Justice, 12 U.C.L.A.L. REv. $381-82$ (1965). 
and the difficulty of prosecution render such statutes ineffectual. ${ }^{5}$ Several states have attempted to provide effective broad-gauged regulation by enacting Consumer Fraud Acts. ${ }^{6}$ In Illinois, for example, intentional misrepresentation and fraud are declared unlawful, and the attorney general is empowered to seek injunctions to restrain unlawful practices; the Massachusetts statute, on the other hand, is directed only at false advertising. But such legislation has provided meager protection for the defrauded consumer due to the limited scope of administration and enforcement. ${ }^{7}$

The response of the legal profession has been to provide group legal services $^{8}$ and to establish neighborhood legal services. ${ }^{9}$ Nevertheless, it seems clear that such legal services will not be able to deal with the

5 Every state has a Retail Installment Sales Act with various provisions for form and disclosure. Violation is usually a misdemeanor. For full citations see CURRAN, op. cit. supra note 2, at 91-123, 361-78. Most states also declare intentionally false advertising to be a misdemeanor. See, e.g., IlL. REv. Stat. ch. 1211/2, § 157.21 (Supp. 1965). But criminal sanctions achieve limited deterrence. First, criminal provisions must be strictly construed and the activity must be clearly within the category proscribed. Tollison v. George, 153 Ga. 612, 112 S.E. 896 (1922); Di Nome v. Personal Fin. Co., 291 N.Y. 250, 52 N.E.2d 117 (1943). See also Comment, Translating Sympathy for Deceived Consumers Into Effective Programs for Protection, 114 U. PA. L. REv. 395, 425 (1966); Comment, Enforcement of Consumer Credit Regulation, 55 Nw. U.L. REV. 403, 411 (1960). Secondly, for many such violations there is the difficulty of proving intent. See Comment, supra, 55 Nw. U.L. REv. at 411; Comment, supra, 114 U. PA. L. REv. at 427 n.249. Finally, public officials almost never prosecute, both because of the above diffculties and because of a general feeling that fraudulent merchants are not criminals. Comment, supra, 114 U. PA. L. REv. at 427, 429.

6 E.g., Ill. REv. Stat. ch. 1211/2, §§ $261-71$ (1963); Mass. GEN. LAws ANN. ch. 226, § 91 (Supp. 1964).

7 Results in Illinois indicate that the act has little deterrent effect. Upon receiving a complaint, a letter of inquiry is sent to the merchant. Most complaints are disposed of by the merchant's reply that he will release the buyer from the contract. Interview with Member of Consumer Fraud Bureau, Illinois Attorney General's Office, Chicago, Ill., Nov. 4, 1965. Since satisfaction of the complaint halts the process, the merchant can buy his peace cheaply and the statute has little influence on business practice. Because more than ninety per cent of the New York Frauds Bureau's activity is devoted to mediating individual buyer and seller disagreements, its efforts are apparently achieving equally limited deterrent effect. Comment, supra note 5, 114 U. PA. L. REv. at 430.

The problem will not be solved, however, by more active prosecution by the bureaus since they will not be in a position to respond to an illegal course of dealing by merchants in local neighborhoods without vast expansion of their resources and manpower. Because local consumer problems and the need for injunctive relief are apparent to local legal aid offices, a theory for private locally initiated relief sought through the resources of expanded legal services would be of significant utility.

8 See, e.g., Committee Report on Group Legal Services, 39 S.B.J. CaL. 639 (1964); The Availability of Counsel and Group Legal Services: A Symposium, 12 U.C.L.A.L. REV. 279 (1965); Note, Group Legal Services, 79 HARv. L. REv. 416 (1965).

9 The Extension of Legal Services to the Poor (Conference Proceedings) 71-131 (1964); WALD, op. cit. supra note 4, at 68-109; Carlin \& Howard, supra note 4; Cratsley, Volunteer Neighborhood clinics, 24 BRIEF CASE 29 (1965). 
scope of the problem if limited to independent individual actions. Representative actions or other remedies of wider scope are needed. ${ }^{10}$

This comment proposes an equitable remedy which is responsive to special community needs, which may be initiated within the community, and which will influence future business conduct. Based on the law of nuisance, the suit is designed to permit the victims of illegal business and credit practices to sue to enjoin them on the grounds that, as they are inadequately controlled by existing legal remedies, they constitute what might be termed a commercial nuisance. Although the remedy would be derived not from consumer fraud legislation ${ }^{11}$ but from the common law of nuisance, plaintiffs would in effect be suing as "private attorneys general" 12 to prevent fraudulent practices which are not now deterred by private litigation or the public enforcement of consumer fraud legislation. For example, if a local merchant sells reconditioned television sets as new, a buyer might initiate a suit in his name or on behalf of all those similarly situated, supported by affidavits from others who were affected by this business practice. Upon finding that the activity did constitute a nuisance, the court would enjoin any further fraud by substitution of items for those described in the contract. If the activity is in violation of a statute, an injunction might issue to enjoin its future violation. ${ }^{13}$ Such a suit would not preclude the traditional defenses against enforcement of the contract or a suit to rescind but rather would be an apt supplement to such relief, since damages for past conduct are generally insufficient to protect future customers from injury.

10 Dunham, Research for Uniform Consumer Credit Legislation, 20 Bus. LAw. 997, 1003 (1965). A survey of private and governmental institutions which offer some form of consumer protection observes "that the defrauded consumer [has] . . . very little chance of obtaining satisfactory relief." Comment, supra note 5, 114 U. PA. L. REv. at 397. Although bar-supported legal aid facilities have been available to the poor for a number of years, it has been suggested that their deterrent effect is insignificant because merchants will generally settle with legal aid clients on the correct assumption that very few of their other customers will seek free legal advice. Speech by Bruce Terris, formerly of the General Counsel's Office, Office of Economic Opportunity, Washington, D.C., delivered at the Conference on Consumer Credit and the Poor, The University of Chicago Law School, Nov. 13, 1965.

11 The Massachusetts Consumer Fraud Act, Mass. Gen. LAws ANn. ch. 266, § 91 (Supp. 1964), permits a suit for an injunction by the attorney general or any aggrieved party, but such suits are limited to cases of false advertising. The common law remedy proposed by this comment might also be achieved by amending consumer fraud legislation to permit injunctive relief when an aggrieved party brings suit.

12 See generally Associated Indus. v. Ickes, 134 F.2d 694 (2d Cir. 1943).

13 This is the form of injunction currently issued by Illinois courts in suits by the Attorney General's Office under the Consumer Fraud Act. Interview with Member of Consumer Fraud Bureau, Illinois Attorney General's Office, Chicago, III., Nov. 4, 1965. See note 57 infra for discussion of the problems raised by the enjoining of violations of a statute. 


\section{The Congept of Commercial Nuisance}

For centuries the law of nuisance has provided injunctive relief from individual activity causing harm not justified by its social utility. While private nuisance prevented interferences with the use of private land, public nuisance developed to include an act or omission "which obstructs or causes inconvenience to the public in exercise of rights common to all her Majesty's subjects."14 Public nuisance has traditionally been applied to protect a variety of public interests including health, ${ }^{15}$ morality, ${ }^{16}$ safety, ${ }^{17}$ and convenience. ${ }^{18}$ In this century it has also been applied to commercial transactions which violate usury laws.

In the leading commercial nuisance case, State ex rel. Smith $v$. McMahon, ${ }^{19}$ the Kansas Supreme Court held that the attorney general could bring suit to enjoin two defendants from violation of noncriminal usury statutes and to have a receiver appointed to wind up outstanding usurious loans. The crucial fact, in the court's view, was that the statute prohibiting usury furnished "no practical relief" 20 because it provided no criminal penalties and borrowers did not dare assert their civil remedies for fear that garnishment of their wages by creditors would result in their being fired. The states's cause of action has become regarded as settled law in Kansas. ${ }^{21}$

Several other states have followed McMahon and have enjoined continuous violations of their usury statutes.22 In each case, courts

14 Mayor and Council of Alpine v. Brewster, 7 N.J. 42, 49-50, 80 A.2d 297, 300 (1951). For two extensive histories of the early common law development of nuisance see McRae, The Development of Nuisance in the Early Common Law, I U. FLA. L. REv. 27 (1948), and Newark, The Boundaries of Nuisance, 65 L.Q. REv. 480 (1949).

15 E.g., Seigle v. Bromley, 22 Colo. App. 189, 124 Pac. 191 (1912); Durand v. Dyson, 271 Ill. 382, IlI N.E. 143 (1915).

16 E.g., Weis v. Superior Court, 30 Cal. App. 780, 159 Pac. 464 (1916); People ex rel. Dyer v. Clark, 268 IIl. 156, 108 N.E. 994 (1915); Wilson v. Parent, 228 Ore. 354, 365 P.2d 72 (1961).

17 E.g., State ex rel. Hopkins v. Excelsior Powder Mfg. Co., 259 Mo. 254, 169 S.W. 267 (1914); State ex rel. Marron v. Compere, 44 N.M. 414, 103 P.2d 273 (1940); Parker v. City of Fort Worth, 281 S.W.2d 721 (Tex. Civ. App. 1955).

18 E.g., Shamhart v. Morrison Cafeteria Co., 159 Fla. 629, 32 So. 2d 727 (1947); Tushbant v. Greenfield's, Inc., 308 Mich. 626, 14 N.W.2d 520 (1944); Town of Mount Pleasant v. Van Tassell, 7 Misc. 2d 643, 166 N.Y.S.2d 458 (Sup. Ct. 1957), aff'd, 6 App. Div. 2d 880, 177 N.Y.S.2d 1010 (1958).

$10128 \mathrm{Kan} .772,280$ Pac. 906 (1929).

20 Id. at 775, 280 Pac. at 907 (1929).

21 See State ex rel. Fatzer v. Miller, 177 Kan. 324, 279 P.2d 223 (1955), where the only question was whether or not the defendant had actually committed usury. The defendant did not question the state's ability to sue to enjoin his activity if it was usury. See Briefs of Counsel, 52 A.L.R.2d 693 (1957).

22 The states following McMahon are Alabama, Florida, Kansas, Kentucky, Minnesota, Nebraska, and North Dakota. See, e.g., Larson v. State ex rel. Patterson, 266 Ala. 589, 97 So. 
found that because the public policy against usury was inadequately - enforced, either by individual actions taken one by one or by criminal prosecutions, a nuisance existed and future violations of the statute were enjoined.

Commercial fraud presents much the same justification for finding an enjoinable nuisance. ${ }^{23}$ The central problem is to define the elements which indicate that relief is inadequate. Since this is the same problem faced by the several state courts which have considered the usurynuisance cases, analysis of the factors considered significant there should prove helpful in developing the doctrine of commercial nuisance.

2d 776 (1957); State ex rel. Embry v. Bynum, 243 Ala. 138, 9 So. $2 d 134$ (1942); State ex rel. Moore v. Gillian, 141 Fla. 707, 193 So. $2 d 751$ (1940); State ex rel. Beck v. Basham, 146 Kan. 181, 70 P.2d 24 (1937); Commonwealth ex rel. Grauman v. Continental Co., $275 \mathrm{Ky} .238$, 121 S.W.2d 49 (1938); State ex rel. Goff v. O'Neill, 205 Minn. 366, 286 N.W. 316 (1939); State ex rel. Beck v. Associates Discount Corp., 162 Neb. 683, 77 N.W.2d 215 (1956); State ex rel. Spillman v. Beck Fin. Corp., 118 Neb. 382, 225 N.W. 46 (1929); State ex rel. Burgum v. Hooker, 87 N.W.2d 337 (N.D. 1957). But see Ex parte Hughes, 133 Tex. 505, 129 S.W.2d 270 (1939), a habeas corpus proceeding, in which petitioner, a defendant in the state's suit for an injunction, had been jailed for contempt when he refused to present his subpoenaed business records. He contended that in a suit by the state a court of equity had no jurisdiction to enjoin the violation of a statute which only created private rights in the victims, since the state had no property right in the case. He further argued that inadequacy of enforcement was strictly a legislative concern and that judicial imposition of penalties went beyond the court's jurisdiction. His writ was granted. In response to this case the Texas legislature enacted a statute giving the attorney general power to bring such suits. Tex. Rev. Crv. Stat. AnN. art. 4646(b) (Supp. 1965). See also People ex rel. Stephens v. Seccombe, 103 Cal. App. 306, 284 Pac. 725 (1930), which is frequently cited for the proposition that criminal usury is not an enjoinable nuisance but which in fact was decided on a pleading point.

23 To suggest that the concept of commercial nuisance which developed under the usury statutes should be extended to include illegal business practices is not to argue that usury statutes be extended to cover installment contracts. It is generally settled that price increases on installment sales will not be considered interest under the usury statutes. Nevertheless, the assumption underlying that doctrine, which was that whereas borrowers are often driven to the mercies of lenders by necessity, purchasers on credit are capable of rational economic decisions and choices, CURRAN, op. cit. supra note 2, at 1-4, is challenged by recent studies of purchasing habits in areas of urban poverty, see CAPLoviTz, op. cit. supra note 1 , at 13 .

Only Arkansas and Nebraska apply usury ceilings to installment contracts. See CuRRAN, op. cit. supra note 2, at 83-90. In some jurisdictions, courts have held that a purported sales contract was in fact a loan and subject to the usury statutes when executed by a vendor and buyer with the assistance, advice, and knowledge of a third party finance company who then bought the contract from the vendor at a discount. Beatty v. Franklin Inv. Co., 319 F.2d 712 (D.C. Cir. 1963); Daniel v. First Nat'l Bank, 227 F.2d 353 (5th Cir. 1955). Most jurisdictions, however, would not term such a transaction a loan, e.g., Carolina Indus. Bank v. Merrimon, 260 N.C. 335, 132 S.E.2d 692 (1963), and will allow the jury to determine the true nature of the transaction only when a loan is "clearly clothed with the trappings of a sale" to avoid the usury statutes. CuRRAN, op. cit. supra note 2, at 84. For a discussion of the tests used by various states see CuRRAN, op. cit. supra note 2, at 13-14, 83-90, and materials cited therein. 
Most of the usury cases turned in part on the poverty of the borrowers and their consequent inability to retain a lawyer to assert their defenses. ${ }^{24} \mathrm{~A}$ second major factor given recognition was that the small amounts at stake discouraged litigation whether or not the buyers were poor. ${ }^{25}$ Third, the courts of equity perceived that buyers might fail to initiate suits for such noneconomic reasons as ignorance of their legal rights ${ }^{26}$ or fear of reprisals by local creditors. ${ }^{27}$ The characteristic common to each of these elements is the discouragement of litigation necessary to control practices which are against public policy; each element is relevant to fradulent or illegal commercial practices as well as to usury.

A different set of problems arises when the commercial activity involves criminal sanctions because of the traditional rule that equity will not enjoin a crime. ${ }^{28}$ Of those jurisdictions having statutes imposing criminal liability for usury, to return to that example, two states have refused to issue injunctions. In State ex rel. Boykin v. Ball Investment $\mathrm{Co}^{29}$ the Georgia Supreme Court held that the state had an adequate remedy in the criminal courts and that if the criminal penalties were an insufficient check on usury "appeal should be made to the lawmakers." Three other jurisdictions, however, have refused to consider the existence of a criminal statute determinative and have found an enjoinable

24 Larson v. State ex rel. Patterson, 266 Ala. 589, 97 So. 2d 776 (1957); State ex rel. Goff v. O'Neill, 205 Minn. 366, 286 N.W. 316 (1939); cf. Nash v. State, 271 Ala. 173, 123 So. 2d 24 (1960), which held that when there was no evidence to indicate that a substantial portion of the borrowers were poor, no injunction would issue. $C f$. the significance of poverty and the consequences of inadequate counsel in recent criminal cases: " $[T]$ he conditions produced by the financial incapacity of the accused are detrimental to the proper functioning of the system of justice and ... the loss in vitality of the adversary system ... significantly endangers the basic interests of a free community." REPORT OF THE Committee on Poverty and the Administration of Federal Criminal Justice 11 (1963), quoted in part in Escobedo v. Illinois, 378 U.S. 478, 490 n.13 (1964).

25 State ex rel. Goff v. O'Neill, 205 Minn. 366, 286 N.W. 316 (1939). Equity has fashioned remedies for the protection of the small stakeholder in the development of the stockholders' derivative suit on the ground that the interests are small and the laws controlling corporate activities are not self-regulating. See Cohen v. Beneficial Indus. Loan Corp., 337 U.S. 541, 547-48 (1949). See also Kalven \& Rosenfield, The Contemporary Function of the Class Suit, 8 U. CHI. L. REv. 684 (194I), suggesting that the class action device be adapted to benefit the small stakeholder. But see Comment, Recovery of Damages in Class Actions, 32 U. CHI. L. REv. 768 (1965).

20 State ex rel. Burgum v. Hooker, 87 N.W.2d 337 (N.D. 1957).

27 State ex rel. Smith v. McMahon, 128 Kan. 772, 280 Pac. 906 (1929).

28 See, e.g., State v. Davis, 65 N.M. 128, 333 P.2d 613 (1958); Elizabeth City v. Aydlett, 198 N.G. 585, 152 S.E. $681(1930)$.

29191 Ga. 382, 12 S.E.2d 574 (1940). Accord, Commonwealth v. Stratton Fin. Co., 310 Mass. 469, 38 N.E.2d 640 (1941).

30 State ex rel. Boykin v. Ball Inv. Co., 191 Ga. 382, 395, I2 S.E.2d 574, 581 (1940). 
nuisance in spite of the criminal nature of the activity. ${ }^{31}$ These cases distinguish between the single violation which would constitute a crime and repeated violations which, in some circumstances, would not only be a series of crimes but a nuisance as well. ${ }^{32}$ Accordingly, while no court has held that violation of the usury statutes is itself a nuisance, courts have considered such factors as harm to public welfare, ${ }^{33}$ the number and feasibility of criminal actions required to protect borrowers, ${ }^{34}$ and the poverty of borrowers and their fear of initiating criminal actions against their creditors ${ }^{35}$ in determining that criminal activity is a nuisance.

If the elements accorded importance in the usury cases occur in the comparable commercial context of retail sales transactions, there would exist ample precedent for relying on the nuisance concept. A further consideration recognized in the usury area is common also to commercial transactions: if courts often become parties to unscrupulous practices by enforcing uncontested default judgments, by issuing writs of garnishment, and by enforcing confessions of judgments, the image of their integrity may be undermined. ${ }^{36}$ In light of the courts' own interest and the strong equitable considerations favoring preventive relief in the absence of effective alternative regulation, it would seem that the intervention of equity is not inappropriate.

31 State ex rel. Moore v. Gillian, 141 Fla. 707, 193 So. 751 (1940); Commonwealth ex rel. Grauman v. Continental Co., 275 Ky. 238, 121 S.W.2d 49 (1938); State ex rel. Burgum v. Hooker, 87 N.W.2d 337 (N.D. 1957).

32 Although equity will not enjoin an act merely because it is a crime, e.g., State v. Davis, 65 N.M. 128, 333 P.2d 613 (1958), equity may intervene if some additional factor makes the activity a public nuisance. Town of Linden v. Fischer, 154 Minn. 354, 191 N.W. 901 (1923) (unlicensed dance hall held an enjoinable public nuisance since public morals were threatened); Montana Milk Control Bd. v. Rehberg, 141 Mont. 149, 376 P.2d 508 (1962) (unauthorized sale of milk was both a crime and enjoined as a threat to public health); People ex rel. Bennett v. Laman, 277 N.Y. 368, 14 N.E.2d 439 (1938) (unlicensed practice of medicine held both a crime and an enjoinable public nuisance). See generally Caldwell, Injunctions Against Crimes, 26 ILL. L. REv. 259 (1931); Comment, Injunction of Crime Without Statutory Authority, 23 ALBANy L. REv. 361 (1959). The problems raised by injunctions to enforce statutes are discussed in note 57 infra.

33 State ex rel. Moore v. Gillian, 141 Fla. 707, 193 So. 751 (1940). See also cases cited note 32 supra.

34 Commonwealth ex rel. Grauman v. Continental Co., $275 \mathrm{Ky} .238,121$ S.W.2d 49 (1938). Cf. Meyer v. Seifert, 216 Ark. 293, 225 S.W.2d 4 (1949) (enjoining a crime because on its face the penalty appeared to be an ineffective deterrent); State v. Red Owl Stores, Inc., 253 Minn. 236, 92 N.W.2d 103 (1958) (enjoining a crime which could only be deterred if the sanctions were repeatedly imposed). See also Harvey v. Prall, 250 Iowa 1111, 97 N.W.2d 306 (1959); People ex rel. Bennett v. Laman, 277 N.Y. 368, 14 N.E.2d 439 (1938). 35 State ex rel. Burgum v. Hooker, 87 N.W.2d 337 (N.D. 1957).

36 See Larson v. State ex rel. Patterson, 266 Ala. 589, 97 So. 2d 776 (1957). 


\section{The Mechanics of a Commercial Nuisance Suit}

Even if a merchant's activity seems to constitute a public nuisance calling for the intervention of equity, there remain difficult procedural problems before a suit can be successfully maintained by aggrieved individuals. General nuisance theory is clear in giving the state standing to enjoin a public nuisance. ${ }^{37}$ Thus, as the usury cases suggest, the state may sue on a nuisance theory to protect its citizens from the injury occasioned by consumer fraud even in the absence of consumer fraud legislation. Although such a common law remedy may be helpful to the state in a jurisdiction where statutory provisions for injunctive relief are limited, it is a premise of this comment that private litigation would be more responsive to consumer fraud situations. ${ }^{38}$ But when aggrieved individuals initiate a commercial nuisance suit, problems of standing arise in addition to the perennial equitable question of the scope of the injunction. Although a corollary to the public nuisance concept declares a nuisance to be abatable only by public prosecution, a variety of technical formulas has been devised to grant a private party standing. ${ }^{39}$

37 State ex rel. Williams v. Karston, 208 Ark. 703, 187 S.W.2d 327 (1945); People ex rel. Dyer v. Clark, 268 Ill. 156, 108 N.E. 994 (1915); People ex rel. Bennett v. Laman, 277 N.Y. 368, 14 N.E.2d 499 (1938).

38 One potential source of consumer protection is afforded by the cause of action which a merchant may bring to enjoin unlawful competition. This line of cases is not based on nuisance but rather seeks to protect the property interest which a merchant is deemed to have in his lawfully operated business. Not only have courts been willing to consider lawful business as a property right, but they have also been exceedingly liberal with the quantum of evidence required to prove damage. In Featherstone v. Independent Serv. Station Assn. of Texas, 10 S.W.2d 124 (Tex. Civ. App. 1928), an injunction was granted against the defendants' illegal lottery. The only evidence of damage was the plaintiff's testimony that customers had left his service station when they discovered that he did not give away lottery tickets. Accord, Glover v. Malloska, 238 Mich. 216, 213 N.W. 107 (1927). But se'e Moon v. Clark, 192 Ga. 47, 14 S.E.2d 481 (1941), in which the facts were identical but the court refused to find a public nuisance. In Alper v. Las Vegas Motel Ass'n, 74 Nev. 135, 325 P.2d 767 (1958), the only evidence of injury from defendant's statutorily proscribed advertising was that plaintiff's prospective customers had told him that they knew they could get cheaper accommodations elsewhere. Courts have hesitated to enforce such controversial legislation as Sunday Closing Laws. See Chapter 215. Associated Master Barbers and Beauticians v. Brown, 315 S.W.2d 17 (Tex. Civ. App. 1958), which held that the plaintiff had no property right in future customers. Accord, York v. American Serv. Co., 204 Tenn. 173, 319 S.W.2d 76 (1958). Contra, Hickinbotham v. Corder, 227 Ark. 718, 301 S.W.2d 30, motion to vacate denied sub nom. Hickinbotham v. Williams, 227 Ark. 1102, 303 S.W.2d 563, cert. denied, 355 U.S. 841 (1958). For a suggestion that this line of cases be applied to consumer fraud, see Alexander, Fraudulent Installment Sales in Chicago, 41 CHICAGo B. RECORD 285 (1960).

- 39 Sparhawk v. Union Passenger Ry., 54 Pa. 401 (1867); McQueen v. Burkhart, 290 S.W. 577 (Tex. Civ. App. 1956). See also the full discussion of the nuisance doctrine in Mayor and Council of Alpine v. Brewster, 7 N.J. 42, 80 A.2d 297 (1951). 
The most useful formula for a commercial nuisance suit involves a broad exception to the public nuisance standing rule permitting a private citizen to sue to abate a public nuisance if he suffers "special damages." Usually special damages has meant damages different in degree and kind from those suffered by the public at large. ${ }^{40}$ But some courts have viewed this requirement for standing as too strict, and on occasion have even rephrased the "well known exception" to read: "If the proper public official refuses to take action to abate a public nuisance, then any person having an interest in the problem greater than that of the community at large may institute proceedings to abate the public nuisance." 41 Such a construction of the special damages rule confers standing to sue for damage to nonproperty interests. Thus, a woman has sued to enjoin obscene language directed at her, ${ }^{42}$ and parishioners have sued to enjoin the operation of a nearby liquor store which disturbed their church worship. ${ }^{43}$.

40 Page v. Niagara Chem. Div. of Food \& Chem. Corp., 68 So. 2d 382 (Fla. 1953); Karpisek v. Cather \& Sons Constr. Inc., I74 Neb. 234, 117 N.W.2d 322 (1962). The rule was stated in 1855 by an Illinois court to be that: "Equity will grant relief, either at the suit of the public or of the citizen, having an immediate interest therein," Green v. Oakes, 17 IIl. 249, 251 (1855), but subsequent Illinois courts have followed the degree and kind rule even while citing Green as authority. See, e.g., Fors v. Anderson, 270 III. 45, 110 N.E. 361 (1915).

41 Morse v. Liquor Control Comm'n, 319 Mich. 52, 58, 29 N.W.2d 316, 319 (1947). Accord, Garver v. San Pedro, L.A., \& S.L. Ry., 151 Fed. 334 (S.D. Cal. 1906); Hampton v. North Carolina Pulp Co., 223 N.C. 535, 27 S.E.2d 538 (1943); Columbia River Fisherman's Protective Union v. City of St. Helens, 160 Ore. 654, 87 P.2d 195 (1939). The Hampton opinion considers the degree and kind rule at length and rejects it. See also the discussion of special damages in Bowlin v. George, 239 S.C. 429, 123 S.E.2d 528 (1962). But see Smedberg v. Moxie Dam Co., 148 Me. 302, 92 A.2d 606 (1952), and Kuehn v. City of Milwaukee, 83 Wis. 583, 53 N.W. 912 (1892), which refuse to reject the degree and kind rule.

42 Wilson v. Parent, 228 Ore. 354, 365 P.2d 72 (1961).

43 Morse v. Liquor Control Comm'n, 319 Mich. 52, 29 N.W.2d 316 (1947). The original justification for the rule that only the state could sue for a public nuisance was twofold. First, public nuisance developed as a criminal offense over which civil courts could have no jurisdiction. Second, there was a feeling that an individual should not have a cause of action for damages which he shared with the public since a multiplicity of actions would then be possible. See Mayor and Council of Alpine v. Brewster, 7 N.J. 42, 80 A.2d 297 (1951). Nevertheless, when parties before the court show more than nominal damages or when they seek an injunction, courts have used the special damage exception and others to find standing. When the injury is to land, courts find an element of private nuisance within the larger public nuisance. Mayor of Georgetown v. Alexandria Canal Co., 37 U.S. (12 Pet.) 91 (1838); Klumpp v. Rhoads, 362 Ill. 412, 200 N.E. 153 (1936); Van Cortlandt v. New York Cent. R.R., 265 N.Y. 249, 192 N.E. 401 (1934). Another formula achieving the same result, terms the nuisance a "mixed" one. Markey v. Danville Warehouse \& Lumber, Inc., 119 Cal. App. 2d 1, 259 P.2d 19 (1953); Northern Ind. Public Serv. Co. v. Vesey, 210 Ind. 338, 200 N.E. 620 (1936); Bishop Processing Co. v. Davis, 213 Md. 465, 132 A.2d 445 (1957); Bowlin v. George, 239 S.C. 429, 123 S.E.2d 528 (1962). These exceptions, considered with the "special damages" exception discussed above, probably indicate that the rule itself has been undermined and should be restated to allow any party showing actual 
In some jurisdictions, then, standing can be shown by establishing that the victims complaining of the activity have suffered "directly" or "in greater degree" than the public. ${ }^{44}$ Even in jurisdictions which adhere to the stricter requirement that the damage suffered by the plaintiffs must be clearly distinguishable from that suffered by the community at large, it could be maintained that since the harm to the community which may result from damage to future buyers and loss of public faith in the courts is different in degree and kind from the actual loss suffered by the named plaintiffs from garnishment, attachment, or substitution of low quality goods, the standing requirement is satisfied.

If proof of special damages gives private individuals standing to sue, the nuisance suit offers special procedural advantages because affidavits or testimony from other victims of the same activity may be introduced to prove that the nuisance is in fact a public one and that there has been damage. ${ }^{45}$ Although indigent consumers are usually reluctant to bring actions or even to appear in court, they may well find safety in numbers and security in a community suit against a common nemesis. Since it would clearly be unfair to term a business practice a public nuisance on the basis of one illegal contract, the number of affidavits must be sufficient to convince the court that the activity represents a course of dealing. ${ }^{46}$ In making such a determination, the court might properly take judicial notice of the reluctance or inability of the victims to exercise their legal rights. For proof of damages, buyers' testimony may indicate that there has been damage to a sufficient number of past and future buyers to constitute "the aggregation of private injuries ... so ... extensive as to constitute a ... wrong against the community," thus meriting relief under one version of the public nuisance concept. ${ }^{47}$ On the other hand, there may be a simple finding that a broader public

damages to maintain the suit. See Hampton v. North Carolina Pulp Co., 223 N.C. 535, 27 S.E.2d 538 (1943). See also Prosser, TorTs 609 (3d ed. 1964), for a similar analysis. Nevertheless, it is safer to plead a commercial nuisance suit within the stated standing rules of the particular jurisdiction.

44 See, e.g., cases cited note 41 supra.

45 Bishop Processing Co. v. Davis, 213 Md. 465, 132 A.2d 445 (1957).

46 In State ex rel. Burgum v. Hooker, 87 N.W.2d 337 (N.D. 1957), fifteen affidavits were sufficient to show a public nuisance, whereas in People v. Seccombe, 103 Cal. App. 306, 284 Pac. 725 (1930) (dictum), two were said to be insufficient. Since both the nature of the alleged nuisance and the number of people affected are before the court at the beginning of the suit, it is possible to protect the defendant from harassment by frivolous suits by dismissing them early in the proceedings and leaving the parties to their individual remedies.

47 Sullivan v. American Mfg. Co., 33 F.2d 690, 692 (4th Cir. 1929), quoting Wesson v. Washburn Iron Co., 95 Mass. (13 Allen) 95, 102 (1866). Accord, People v. Rubenfeld, 254 N.Y. 245, 172 N.E. 485 (1930) (Cardozo, J.). 
nuisance is damaging the community as well as the individual victims. ${ }^{48}$

In the typical nuisance case, an action by an individual or class has the same result as a suit on behalf of the state because the injunction obtained by the named plaintiff forces cessation or modification of the activity in general. Thus, if an individual brings an action to enjoin an activity producing noise, smell, or dust, abatement for the named plaintiff results in abatement for the public as well. Commercial nuisance, however, differs from previous nuisance cases in that an injunction issued for the benefit of the named plaintiff will not eliminate the source. The nuisance may be continued against the world while abated as to the plaintiff.

Since the previous case law arose from situations where granting the injunction to the individual also abated the public nuisance, there exists little authority on whether the scope of an injunction can be expanded to protect persons other than the plaintiff if a nuisance is adjudged public in nature. One court's view of the special damage exception was that courts of equity exercised jurisdiction "not for the purpose of suppressing a public nuisance, but to redress a private wrong done to the individual." 49 The Supreme Court, however, has taken the opposite view. In Mississippi \& Missouri R.R. v. Ward, ${ }^{50}$ an 1862 case, a part owner of a Mississippi riverboat brought an action to abate the public nuisance of a railroad bridge across the river. Although the bill was dismissed on other grounds, the Court discussed the position of the specially damaged plaintiff:

A bill in equity to abate a public nuisance, filed by one who has sustained special damages, has succeeded to the former mode in England of an information in Chancery, prosecuted on behalf of the Crown, to abate or enjoin the nuisance as a preventive remedy. The private party sues rather as a public prosecutor than on his own account .... He seeks redress of a continuing trespass and wrong against himself, and acts in behalf of all others, who are or may be injured . ... ${ }^{51}$

48 In the usury cases, although the state presented no evidence except the testimony of the borrowers, the court made such findings as general economic decline and loss of faith in the courts, State ex rel. Embry v. Bynum, 243 Ala. 138, 146, 9 So. 2d 134, 142 (1942), and "detriment of our people as a whole," State ex rel. Beck v. Basham, 146 Kan. 181, 183, 70 P.2d 24, 25 (1937). Such general conclusions based on the testimony of the injured are proper findings in nuisance suits. See Arizona Copper Co. v. Gillespie, 12 Ariz. 190, 100 Pac. 465 (1909) (finding general economic decline in the community); Morse v. Liquor Control Comm'n, 319 Mich. 52, 58, 29 N.W.2d 316, 319 (1947) (finding of "special" nature of plaintiff's damages based on judicial notice).

49 Hedden v. Hand, 90 N.J. Eq. 583, 590, 107 Atl. 285, 288 (1919).

50 67 U.S. (2 Black) 485 (1862).

51 Id. at 492. 
A subsequent federal court decision supported this view and offered the additional rationale that relief is granted in special damage cases "not solely because the nuisance is private so far as [the plaintiff] is concerned, but because it is public, and the relief will benefit the public."s2

Although the language of the federal courts appears to permit injunctions of broad scope, no court has directly faced the problem. In all previous nuisance cases protection of the specially damaged plaintiff has adequately protected the public as well. One early case, however, does indicate that courts will frame relief to protect the public interest even if that requires a broader inunction than protecting the named plaintiff would require. In that case, the Court of Appeals of Colorado held that a pig farm was a nuisance both to the public and to the named plaintiff, an adjoining landowner. Hence the trial court's order, which enjoined only activity which would be offensive to the plaintiff, was expanded by the reviewing court to forbid the use of the defendant's property "in such manner as will be offensive or dangerous to the health of the plaintiff and the public."53

If such an approach were generally accepted, or if courts accepted the dictum of the Ward case, a specially damaged plaintiff might be allowed to abate a public nuisance in its entirety through a commercial nuisance suit. Such a conclusion is further supported by the fact that protection of consumers from fraudulent sales practices would be a significant "social benefit," which constitutes a relevant factor in determining the scope of injunctions for nuisance ${ }^{54}$ and of equity protection in general..$^{55}$

The content and form of the injunction pose additional problems. -The injunction would of course proscribe such activity as had been found to be a nuisance. But to prevent the merchant from avoiding the injunction by slight modification of his contracts, the injunction must reach conduct of "similar effect." 56 Thus, the merchant who delivers reconditioned television sets after representing them as new would be enjoined from selling goods of different quality from those described in the contract. Finally, as previously noted, if conduct is in violation

52 Woodruff v. North Bloomfield Gravel Mining Co., 18 Fed. 753, 788-89 (C.C.D. Cal. 1884).

53 Siegle v. Bromley, 22 Colo. App. 189, 200, 124 Pac. 191, 195 (1912).

54 See Woodruff v. North Bloomfield Gravel Mining Co., 18 Fed. 753 (G.C.D. Cal. 1884).

55 United States v. First Nat'l City Bank, 379 U.S. 378 (1965), quoting Virginian Ry. v. System Fed'n No. 40, 300 U.S. 515, 552 (1937): "Courts of equity may, and frequently do, go much farther ... to give ... relief in furtherance of the public interest than they are accustomed to go when only private interests are involved." 379 U.S. at 383.

56 See United States v. Parkinson, 240 F.2d 918 (9th Cir. 1956), in which the defendant was enjoined from violation of the federal Food, Drug, and Cosmetic Act with respect to certain enumerated drugs " "or other similar drugs, or other drugs offered for similar purposes." "Id. at 919. 
of a statute, the injunction would be cast in its terms. ${ }^{57}$ Thus, effective enforcement of legislation already enacted may be the most significant function of the commercial nuisance suit.

\section{Conclusion}

The legal system currently offers inadequate redress for many of the urban poor who are injured by unscrupulous commercial practices. Few victims exercise their legal rights due to the small stakes in litigation, their financial inability to retain counsel, and their lack of comprehension of commercial and legal institutions. As a result, those who do complain and seek redress should be allowed to serve as representatives of their community. The concept of commercial nuisance offers a possible theory for such actions. Because only fraudulent, unconscionable, or illegal business practices could be enjoined, the doctrine need not threaten the legitimate businessman, and it offers at least a partial solution to the problem of inadequate legal representation of the poor.

57 This was the form of the injunction in each of the usury cases. See also the cases enjoining crimes cited notes 32 \& 34 supra. The use of the injunction as an enforcement device raises a number of problems of fairness to the defendant. First, if the injunction does not clearly describe the prohibited conduct, the defendant will be left in doubt as to what constitutes lawful activity. Second, the defendant has no right to a jury either to find the facts which give rise to the issuance of the injunction or to determine whether there has been a violation in a contempt proceeding. The practice of enjoining labor unions and violators of Prohibition laws led to sharp criticism of the device. See, e.g., Black, The Expansion of Criminal Equity Under Prohibition, 5 Wus. L. REv. 412 (1930); Dunbar, Government by Injunction, 13 L.Q. REv. 347 (1897). Subsequent use of injunctions, however, has been sufficiently fair to win general approval. See generally Developments in the Law-Injunctions, 78 HARv. L. REv. 994 (1965); Comment, The Statutory Injunction as an Enforcement Weapon of Federal Agencies, 57 YALE L.J. 1023 (1948).

In FTC v. Ruberoid Co., 343 U.S. 470 (1953), the Supreme Court affirmed an injunction cast in the terms of a broad statute on the grounds that the defendant might successfully avoid a narrower one. The practice under the Illinois Consumer Fraud Act is to enjoin future violation of the act, which in effect enjoins future "fraud, intentional misrepresentation, or false advertising." Interview with Member of Consumer Fraud Bureau, Illinois Attorney General's Office, Chicago, Ill., Nov. 4, 1965.

Dictum in United States v. Barnett, 376 U.S. 681, 694-95 n.12 (1964), indicates that the Court may in the future require a jury trial in contempt proceedings in which the penalty is a long prison term. See generally Teff, United States $v$. Barnett: "Twas a Famous Victory," 1964 SuPREME CouRT REv. 123. 